\title{
METHODS OF MAXIMUM DISCHARGE COMPUTATION IN UNGAUGED RIVER BASINS. REVIEW OF PROCEDURES IN ROMANIA.
}

\author{
Anna Izabella VODA ${ }^{1}$, Adrian Constantin SARPE ${ }^{2}, M_{i h a i} \mathrm{VODA}^{3}$
}

DOI: 10.21163/GT_2018.131.12

\begin{abstract}
:
Maximum discharge determination on small river basins with no hydrological measurement utilities is important for the rainfall-runoff correlation and the accurate assessment of the watershed surface flow effects. Discharge transfer time calculation from rainfall to runoff requires correct determined hydrological parameters. The focus of this article is the evaluation of Romanian methodologies used for maximum discharge computation in ungauged river basins. Our research for ungauged small river basins study methodology was carried on using remote sensing, GIS and regional datasets. Field work on significant small catchments was necessary for the basin morphological features assessment and land cover characteristics validation. We found that the Romanian rational methodology is widely used according to national landscapes features classification, applicable to a considerable number of ungauged river basins. Our study presents the benefits and limitations of the official Romanian methodologies used for small ungauged river basins scientific assessment and hydrological calculations.
\end{abstract}

Key-words: river basin, ungauged basin, rational method, GIS, maximum discharge.

\section{INTRODUCTION}

The maximum discharge correct computation for ungauged river basins has a significant importance for the safety and reliability of water works planning, flooding estimation and floods protection measures. There is a considerable difficult delimitation between ungauged river basins from the maximum discharge approach. The limit varies according to the geographical position, from upstream mountain river basins to hilly and downstream plain regions.

Romanian ungauged river basins maximum discharge computation is determined using various research approaches, such as Romanian national rational standard methodology (RNS), general or synthesis relations methodology, Q200 and rainfall computation methodology (Diaconu \& Miță, 1997).

Small river basins surfaces under $5-10 \mathrm{~km}^{2}$ are analyzed with the RNS method. The maximum discharge determination for ungauged watersheds surfaces below $1000 \mathrm{~km}^{2}$ is developed with synthesis relations methodology, using measured data from hydrological stations network in representative neighboring river basins or experimental hydrological stations, having the maximum discharge obtained from regular statistical calculations, and from pluvial network system. The methodology based on rain computation is used for the maximum discharge of $1 \%$ probability determination in $5-100 \mathrm{~km}^{2}$ river basins and the Q200 method for 10-1000 km² river basins (Sarpe \& Voda, 2017; Diaconu \& Miță, 1997; Mustață, 1991).

\footnotetext{
${ }^{1}$ Babes Bolyai University, 400006 Cluj Napoca, Romania, vodaizabella@yahoo.com;

${ }^{2}$ Lorraine University, Laboratory LOTERR EA-7304, 57045 Metz, France, adriansarpe@yahoo.com;

${ }^{3}$ Dimitrie Cantemir University, 540545, Targu Mures, Romania, mihaivoda@cantemir.ro;
} 
The maximum discharge computation methodologies require soil, vegetation and land cover assessment. Remote sensing technology is important for river basins outlining process. Eilander et al. (2014) used MODIS and Landsat for maps elaboration and Radarsat for watershed monitoring.

Small river basins rainfall-runoff models constitute indicators of regional water system evolution, being also important for national water resources policies and management plans (Sarpe \& Voda, 2017; Deitch et al., 2016; Haidu \& Ivan, 2016). Reistetter and Russell (2011), analyzed the duration time between the maximum precipitation value and peak flow discharge, emphasizing the importance of rainfall. Fan et al. (2013), suggested that rainfallrunoff correlation is considerably dependent on soil typology. Zégre et al. (2013), assessed the influence of land coverage on overland flow. Choi et al. (2013) created the LSM (land surface model) for catchments stream flow assessment and management. Haidu et al. (2017), created 'The Cluj model for peak flow computation in any point of a hill slope. Bozzano et al. (2017) validated remote sensing methodology with field trips. Ungauged watershed stream flow computation could present errors without onsite validation surveys.

As the National Institute of Hydrology and Water Management (NIHWM) is increasingly recommending the use of RNS for the ungauged small river basins maximum discharge computation, it is worth examining its impact in Romania, where SCS-CN is a pioneer in the process (Sarpe \& Voda, 2017). According to OMMD (2016), Grimaldi et al. $(2012,2013,2015)$ the Rational Formula has to be updated to the new technological trends, which determined significantly improved methodology for river basins maximum discharge evaluation.

\section{RESEARCH METHODOLOGY}

Geographical information system (GIS) represents the main geospatial technology that facilitates the use of DEM (digital elevation model), CLC (Corine Land Cover) and HWSD (Harmonized World Soil Database) for the virtual hidro-maps ellaboration and catchments morphological features comprehension. INIS GeoPortal, developed on Esri Geoportal Server Extension Technology and Google Earth are utilized for geographical data validation, environmental factors assessment (Diaconu \& Serban, 1994; Yu et al., 2000; Reistetter \& Russell, 2011; Jung \& Jasinski, 2015; Győri et al., 2016).

An assessment will first be made of the geographical features of the river basins themselves, on an individual basis. Secondly, the existing hydrological registered measurements are analyzed and then, according to the available hydrometrical database, the proper maximum discharge computation methodology is selected.

Preliminary evaluation phase impose the measurement of the analyzed river basin surface, the forest canopy coefficient calculation, soil types determination and climatic characterization.

The hydrometrical data from the river basin are analyzed based on annual database collected from the hydrological stations, with focus on the exceptional maximum discharges registered, maximum flow volumes and the major floods hydrograph (Diaconu \& Miță, 1997).

A considerable number of ungauged river basin parameters can be determined from regional synthesis studies and should be validated in the field, such as land cover, soil typology and watershed morphometric features (Diaconu \& Serban, 1994; Sarpe \& Voda, 2017). 


\section{THE $Q_{200}$ METHOD}

The $Q_{200}$ method is applied when $200 \mathrm{Km}^{2}$ river basins are selected as reference, with already computed $1 \%$ maximum discharges. For the given surface $F_{b}$ of the river basin that needs to be analyzed, the maximum discharge calculus formula will be (Mustaţă, 1991):

$$
\mathrm{Q}_{\max 1 \% \mathrm{~B}}=\mathrm{q}_{200}\left(200 / \mathrm{F}_{\mathrm{B}}\right)^{\mathrm{n}} \mathrm{F}_{\mathrm{B}}
$$

Where $\mathrm{q}_{200}$ represents the specific maximum discharge with $1 \%$ probability, determined on the $200 \mathrm{~km}^{2}$ river basins surface and expressed in $\mathrm{m}^{3} / \mathrm{s}$ per $\mathrm{km}^{2}$ (Fig. 1). The $n$ parameter is extracted from the $n$ reduction coefficient maps (Diaconu \& Miță, 1997).

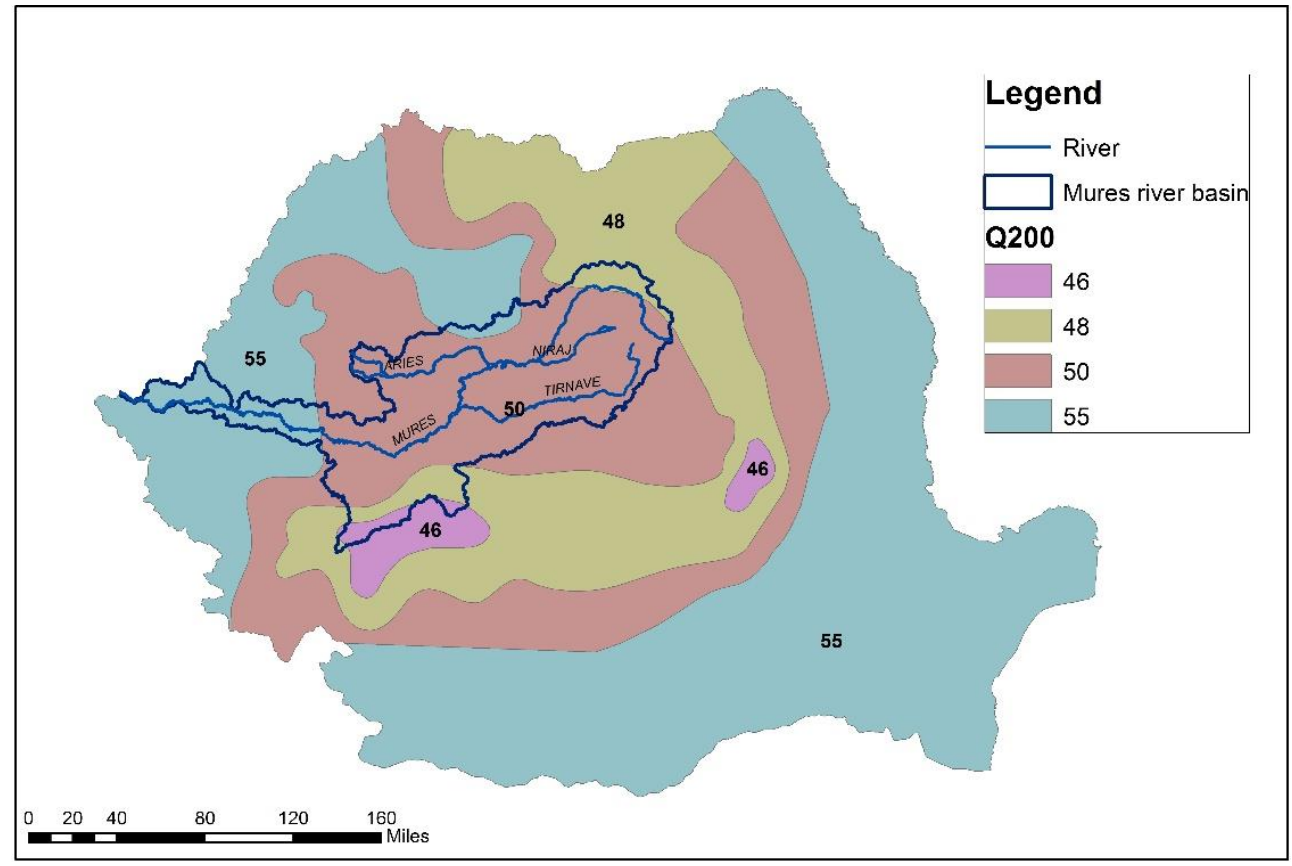

Fig. 1 The q200 specific maximum discharge map.

\section{THE H RAINFALL METHOD}

The $\mathrm{H}$ rainfall method presents a computation formula for the maximum discharges with $1 \%$ probability determination in the river basins with surfaces between 5 and $100 \mathrm{~km}^{2}$ (Mustaţă, 1991):

$$
\mathrm{Qmax} 1 \%=\left(0,28 * \mathrm{C}_{\mathrm{s}} * \mathrm{~F} * \mathrm{H} 60\right) /(\mathrm{F}+1)^{\mathrm{n}}
$$

where the hourly maximum precipitations layer $\left(\mathrm{H}_{60}\right)$ and the $n$ subunitary coefficient are provided by the Romanian standard regionalization (Fig. 2) annexes (Diaconu \& Miță, 1997). The $C_{s}$ parameter represents the runoff coefficient, obtained from the Romanian experimental hydrological stations and representative river basins (Miță \& Muscanu, 1986). 


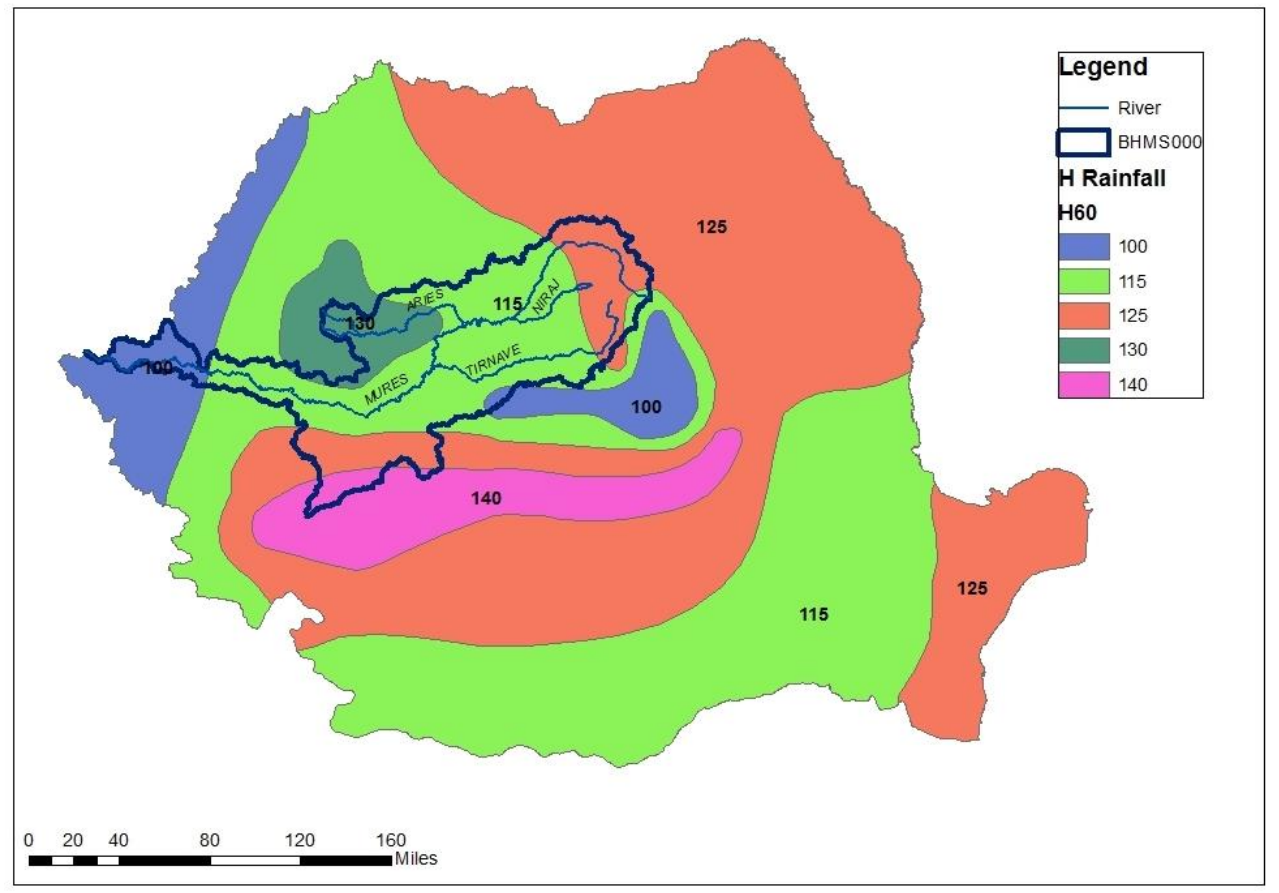

Fig. 2 The $H$ rainfall map.

The $\mathrm{C}_{\mathrm{s}}$ (runoff coefficient) is determined taking into account the river basin soil textures, average slope gradients and forest canopy coefficient. The Arc GIS facilitates the extraction of the slope layer for the analysed river basin providing the catchment slopes and soil textures. LANDCOVER layer computes the forest canopy coefficient (Diaconu \& Miță, 1997).

\section{GENERALIZATION METHOD}

The generalization or synthesis method is considered an indirect approach, applied when hydrological data are missing. The maximum discharge computation is based on neighbouring similar river basins hydrological determinations. The necessary data have to be registered at 4-5 hydrometrical stations located in the analysed watershed proximity. The maximum discharges origins in Romanian river basins are represented mainly by the rainfalls (Mustaţă, 1991).

This methodology cannot be applied in certain situations, such as considerable morphological catchment features differences between the analysed river basin and the referenced ones. Furthermore, the existence of significant surfaces exposed to flooding, the presence of specific soils, for example sandy soils or the water works constructions that are influencing the runoff regime are restricting the methodology application (Diaconu \& Miţă, 1997).

The average altitude of the referenced river basins and their surface have to be relatively similar in order to qualify for generalization methodology establishment (Diaconu \& Serban, 1994). 


\section{THE RATIONAL METHOD (RNS)}

The Romanian national rational standard (RNS) method represents the main maximum discharge computation methodology applied for small ungauged river basins in Romania (Sarpe \& Voda, 2017). The registered rainfalls are considerably influencing the small watersheds water balance. The rational calculus formula is taking into account the average precipitation intensity that is generating the maximum discharge and has a duration that equals the runoff watershed lag time, the runoff coefficient and the analysed river basin surface in square kilometres. $\mathrm{Q}_{\max 1 \%}$ is expressed in $\mathrm{m}^{3} / \mathrm{s}^{*} \mathrm{~km}^{2}$ :

$$
\mathrm{Q}_{\max 1 \%}=\mathrm{B}_{1 \%} * \mathrm{~F}^{(1-\mathrm{n})}
$$

Where $\mathrm{F}$ is the river basin surface in $\mathrm{km}^{2},(1-\mathrm{n})$ is a subunitary parameter and $\mathrm{B}_{1 \%}$ represents the $1 \%$ probability maximum discharge for $1 \mathrm{~km}^{2}$ surface. The $\mathrm{B}_{1 \%}$ parameter is adjusted through an iterative procedure so the maximum discharge calculated from the formula:

$$
\mathrm{Q}_{\max 1 \%}=16.7 * \mathrm{I}_{\mathrm{r} 1 \%} * \mathrm{C}_{\mathrm{r}} * \mathrm{~F} \text {, }
$$

has to coincide with the discharge determined with formula (3) under the 5\% acceptable error. $C_{r}$ is the river basin runoff coefficient and $I_{r 1 \%}$ represents the generating rainfall intensity, directly dependent on the $\mathrm{B}_{1 \%}$ parameter through the overland flow concentration time.

The precipitations that are generating the maximum discharge are considered uniformly distributed on the river basin surface. This is the reason why the application of RNS is limited to the small ungauged river basins with surfaces up to 1000 ha, situated in the hilly and mountainous regions (Diaconu \& Miță, 1997).

The RNS method takes into account the watershed surface typology, the vegetation coverage gradient and the vegetation type (grass, shrubs, forest) before maximum discharge computation. In practice, the following hydrographical parameters are determined (Diaconu \& Serban, 1994):

- $\quad$ F river basin surface - determined with GIS tools

- La river bed length - measured between the river origins and the closing watershed section with GIS tools

- $\quad \mathbf{\Sigma} \mathbf{L}$ the total river bed length including tributaries $-\mathbf{\Sigma} \mathbf{L}=\mathbf{L} \mathbf{a}+\mathbf{\Sigma} \mathbf{L a f l}$

- $\quad \mathbf{L v}$ the average slopes length- $\mathbf{L v}=\mathbf{0 , 5 5} * \mathbf{F} / \mathbf{\Sigma} \mathbf{L}$

- Ia the average river bed slope - $\mathbf{I a}(\mathbf{m} / \mathbf{k m})=\Delta \mathbf{H}(\mathbf{m}) / \mathbf{L a}(\mathbf{k m})$

Environmental factors are conditioning the maximum discharge genesis, the river bed runoff and the overland water flow. The watershed morphological parameters such as soil textures, vegetation typology, watercourse body class, forest canopy gradient and human settlements characteristics have to be evaluated owing to their influence on river flow and maximum discharge formation. On field assessment is recommended for ungauged catchments (Sarpe \& Voda, 2017).

The roughness coefficient determination is preceded by the riverbed barriers or flow obstacles appraisal, water vegetation placements and meandering grade estimation. According to Diaconu \& Miță (1997), the reduction coefficient values for different Romanian geographical areas, the riverbed and slope roughness coefficients are extracted 
from designated tables, elaborated by the National Institute of Hydrology and Meteorology (Diaconu \& Serban, 1994).

\section{DISCUSSION}

The RNS methodology is founded on tailored-made maps, regional stereotypes and generalization documents. According to Musy (1998), Jeon et al. (2014), land cover and soil type assessment have a significant importance for curve number estimation in ungauged river basins. Assigning values for soil permeability, vegetation density and hill slope, the curve number is estimated and used for the maximum potential water retention computation but in ungauged catchments the curve number appraisal is using only land cover and soil type characteristics. Huang et al. (2006) performed the slope inclusion into the curve number estimation method and showed the runoff depth connection to slope values. Jeon et al. (2014) presented the ungauged catchments surface runoff assessment errors generated by the unadjusted curve number variables.

Sarpe \& Voda (2017), observed that the RNS methodology field validation is considerably increasing the maximum discharge computation accuracy if it is correlated with the calibrated river basin surface parameters in GIS data base. Satellite imagery can indicate land cover typology changes, which are considered important predictors for small river basins hydrological processes development. Legal and illegal deforestation activities are significantly disturbing the rainfall-runoff processes, with disastrous effects on a considerable number of Romanian rural communities. Choi (2013) and Posner et al. (2014), showed the importance of mapping products and simulation models for the small watershed protection and flood prevention for refined prognosis of water system evolution.

\section{CONCLUSIONS}

This paper findings are illustrating the rational methodology significant adjustability to Romanian ungauged watershed geographical characteristics. The maximum discharge determination is more accurate and the lag time duration remarkably follows the runoff influencing parameters variation. The time interval between the maximum rainfall moment and the peak stream flow is dependent on the river basin hydrographical features, proving the RNS method flexibility. Furthermore, on field validation required for small catchments hidro-morphology and forest canopy assessment, considerably contributes to RNS methodology proficiency.

The maximum discharge computation methodology for small ungauged watersheds is presenting special particularities, with different elements, in comparison with the maximum discharge determination procedures for bigger river basins.

In small catchments, the rainfall repartition on the basin is more concentrated as compared with the same precipitation quantity registered in larger river basins.

The peak runoff and the floods formed on small watersheds are composing floods on small watersheds in a shorter time interval compared with the wider basins surfaces. This faster runoff concentration process leads to a different methodology approach for the maximum discharge computation according to the size of the ungauged river basins.

The watershed surface roughness characteristics are influencing the conceiving?? and the conditional factors of the peak runoff dynamics. River basin slopes degradation, fast erosional processes and deforestation activities can produce important changes in years or decades. 
The ungauged river basins surface evolution, the runoff coefficient, the roughness effects on the rainfall-runoff system are all quantified in the RNS methodology used for maximum discharge computation.

\section{R E F E R E N C E S}

ArcGIS Server, (2017). Website of ArcGIS Server [Online]. Environmental Systems Research Institute, Available from: www.esri.com/software/arcgis/arcgisserver/, [Accessed December 2017].

Bozzano, F., Mazzanti, P., Perissin, D., Rocca, A., De Pari, P., \& Discenza, M.E. (2017). Basin Scale Assessment of Landslides Geomorphological Setting by Advanced InSAR Analysis. Remote Sensing, 9, 267.

Choi, H.I. (2013). Application of a Land Surface Model Using Remote Sensing Data for High Resolution Simulations of Terrestrial Processes. Remote Sensing, 5, 6838-6856.

Deitch, M.J., Docto, M., \& Feirer, S.T. (2016). A spatially explicit framework for assessing the effects of weather and water rights on streamflow. Applied Geography, 67, 14-26.

Diaconu, C., \& Serban, P. (1994). Sinteze si regionalizari hidrologice, Editura HGA: Bucuresti, Romania, pp. 151-185, 973-98530-8-0.

Diaconu, C., \& Miță, P. (1997). Instrucțiuni pentru calculul scurgerii maxime în bazine mici. I.N.M.H., București, Romania.

Eilander, D., Annor, F.O., Iannini, L., \& van de Giesen, N. (2014). Remotely Sensed Monitoring of Small Reservoir Dynamics: A Bayesian Approach. Remote Sensing, 6, 1191-1210.

FAO/IIASA/ISRIC/ISS-CAS/JRC. (2009). Harmonized World Soil Database (version 1.1)., FAO, Rome, Italy and IIASA, Laxembourg, Austria.

Fan, F., Deng, Y., Hu, X., \& Weng, Q. (2013). Estimating Composite Curve Number Using an Improved SCS-CN Method with Remotely Sensed Variables in Guangzhou, China. Remote Sensing, 5, 1425-1438.

Grimaldi, S., Petroselli, A., \& Romano, N. (2013). Green-Ampt Curve Number mixed procedure as an empirical tool for rainfall-runoff modelling in small and ungauged basins. Hydrological Processing, 27, 1253-1264.

Grimaldi, S., \& Petroselli, A. (2015). Do we still need the Rational Formula? An alternative empirical procedure for peak discharge estimation in small and ungauged basins. Hydrological Science Journal, 60(1), 1-11, DOI:10.1080/02626667.2014.880546.

Grimaldi, S., Petroselli, A., Tauro, F., \& Porfiri, M. (2012). Time of concentration: a paradox in modern hydrology. Hydrological Science Journal, 57(2), 217-228, DOI:10.1080/02626667.2011.644244.

Győri M-M., Haidu I., \& Humbert J., (2016). Deriving the floodplain in rural areas for high exceedance probability having limited data source. Environmental Engineering and Management Journal, 15(8), 1879-1887.

Haidu, I., Batelaan, O., Crăciun, A.I., \& Domniţa, M. (2017). GIS module for the estimation of the hillslope torrential peak flow. Environmental Engineering and Management Journal, 16(5), 1137-1144.

Haidu, I., \& Ivan, K. (2016). Évolution du ruissellement et du volume d'eau ruisselé en surface urbaine. Étude de cas: Bordeaux 1984-2014, France. La Houille Blanche, 5, 51-56.

Haidu, I., \& Ivan, K. (2016). The assessment of the impact induced by the increase of impervious areas on surface runoff. Case study the city of Cluj-Napoca, Romania. Carpathian Journal of Earth and Environmental Sciences, 11(2) 331 - 337.

Huang, M., Gallichand, J., Wang, Z., \& Goulet, M.A. (2006). Modification to the Soil Conservation Service curve number method for steep slopes in the Loess Plateau of China. Hydrological Processes, 20, 579-589.

Jeon, J.-H., Lim, K.J., \& Engel, B.A. (2014). Regional Calibration of SCS-CN L-THIA Model: Application for Ungauged Basins. Water, 6, 1339-1359. 
Jung, H.C., \& Jasinski, M.F. (2015). Sensitivity of a Floodplain Hydrodynamic Model to SatelliteBased DEM Scale and Accuracy: Case Study-The Atchafalaya Basin. Remote Sensing, 7, 7938-7958.

Kim, U., \& Kaluarachchi, J.J. (2008). Application of parameter estimation and regionalization methodologies to ungauged basins of the Upper Blue Nile River Basin, Ethiopia. Journal Hydrology, 362, 39-56.

Miţă, P., \& Muscanu, M. (1986). Small river basins runoff coefficients, Studii şi cercetări de hidrologie : Bucuresti, Romania, pp. 45-58. 53.

Mustață, I. (1991). Instrucțiuni pentru calculul scurgerii maxime în bazine mici. I.N.M.H., București, Romania.

Musy, A. (1998). Hydrologie appliquée. $\mathrm{H}^{*} \mathrm{G}^{*} \mathrm{~A} *$, Bucuresti, Romania, 368 p.

Ordinul MMDD nr. 976/2008. [Online]. Available from: https://lege5.ro [Accessed December 2017].

Posner, A., Georgakakos, K., \& Shamir, E. (2014). MODIS Inundation Estimate Assimilation into Soil Moisture Accounting Hydrologic Model: A Case Study in Southeast Asia. Remote Sensing, 6, 10835-10859.

Reistetter, J.A., \& Russell, M. (2011). High-resolution land cover datasets, composite curve numbers, and storm water retention in the Tampa Bay, FL region. Applied Geography, 31, 740-747.

Sarpe, C. A., \& Haidu, I. (2017). Temporal sampling conditions in numerical integration of hydrological systems time series. Geographia Technica, 12, Issue 1, 2017, 82- 94.

Sarpe, C. A., \& Voda, I. (2017). Small Watershed Hydrological Models - Lag Time Comparation. 3rd PannEx workshop on the climate system of the Pannonian basin. Cluj-Napoca, Romania, 20-21 March 2017; Horvath, C., Croitoru, A. E., Guettler, I., Man, T. C, Bartok, B. Eds.; Romania.

United States Department of Agriculture, Soil Conservation Service (USDA-SCS). (2004). Estimation of Direct Runoff from Storm Rainfall. In National Engineering Handbook; USDASCS: Washington, DC, USA.

USGS (2017) The United States Geological Survey [Online]. Land Cover Trends Geotagged Photography. Available from: https://lta.cr.usgs.gov/lct_photos [Accessed December 2017].

Yu, B., Rose, W.C., Ciesiolka, C.A., \& Cakurs, U. (2000). The relationship between runoff rate and lag time and the effects of surface treatments at the plot scale. Hydrological Science, 45(5), 709726.

Zégre N.P., Maxwell A., \& Lamont, S. (2013). Characterizing streamflow response of a mountaintop-mined watershed to changing land use. Applied Geography, 39, 5-15. 